\title{
Antimicrobial Resistance and Virulence of Staphylococcus spp. in patients from oncologic and non oncologic hospitals of Recife City/PE
}

\author{
Resistência antimicrobiana e virulência de Staphylococcus spp. em pacientes de hospital oncológico e \\ não oncológico da Cidade de Recife / PE \\ Resistencia a los antimicrobianos y virulencia de Staphylococcus spp. en pacientes de un hospital \\ oncológico y no oncológico de la Ciudad de Recife / PE
}

Received: 08/01/2021 | Reviewed: 08/04/2021 | Accept: 08/07/2021 | Published: 08/13/2021

\author{
Marcelle Aquino Rabelo \\ ORCID: https://orcid.org/0000-0003-3176-1008 \\ Universidade Federal de Pernambuco, Brazil \\ E-mail: marcellearabelo@gmail.com \\ Stephanie Targino da Silva \\ ORCID: https://orcid.org/0000-0001-6997-2623 \\ Universidade Federal de Pernambuco, Brazil \\ E-mail: stephanietargino@hotmail.com \\ Jussyêgles Niedja da Paz Pereira \\ ORCID: https://orcid.org/0000-0002-6494-0128 \\ Universidade Federal de Pernambuco, Brazil \\ E-mail: ju-biomed@hotmail.com \\ Natália Regina Souza da Silva \\ ORCID: https://orcid.org/0000-0002-7800-5552 \\ Universidade Federal de Pernambuco, Brazil \\ E-mail: nathregina@gmail.com \\ Vítor Hugo de Arimatéa Rocha \\ ORCID: https://orcid.org/0000-0002-0273-7255 \\ Faculdade Frassinetti do Recife, Brazil \\ E-mail: arimatearocha@gmail.com \\ Paulo Sérgio Ramos Araújo \\ ORCID: https://orcid.org/0000-0002-7839-0737 \\ Fundação Oswaldo Cruz, Brazil \\ E-mail: psergiora@gmail.com \\ Alzira Maria Paiva de Almeida \\ ORCID: https://orcid.org/0000-0002-8304-3182 \\ Fundação Oswaldo Cruz, Brazil \\ E-mail: alzira.almeida@ fiocruz.br \\ Nilma Cintra Leal \\ ORCID: https://orcid.org/0000-0001-9769-7630 \\ Fundação Oswaldo Cruz, Brazil \\ E-mail: nilma.leal@ fiocruz.br \\ Maria Amélia Vieira Maciel \\ ORCID: https://orcid.org/0000-0002-4220-6889 \\ Universidade Federal de Pernambuco, Brazil \\ E-mail: amelia57@gmail.com
}

\begin{abstract}
Staphylococcus spp. is one of the major infection-associated bacteria within health care, especially in intensive care units, and one of principal cause of complication in cancer patients. This study compared the antimicrobial susceptibility profile and frequency of resistance (mec A, blaZ, erm A and erm $\mathrm{C}$ ) and virulence (ica $\mathrm{A}, i c a \mathrm{D}$ and $h l g$ ) genes in Staphylococcus spp. from patients of Oncology Hospital (OH) and University Hospital (UH). The type of the ccr complex was assessed by PCR among the mecA positive isolates from the UH. Higher percentage of susceptible isolates, except for oxacillin and cefoxitin was found among the UH isolates and 27,3\% vancomycin-resistant isolates were identified through the screening spot; 41 isolates displayed the MLSB $_{c}$ phenotype and five the MSLB phenotype, and one isolate from the $\mathrm{OH}$ displayed the constitutive phenotype erm $\mathrm{C}$ gene. The $\operatorname{ccr}$ types I and II were identified with a higher frequency of $c c r$ type I. No statistically significant difference was found in the frequency of the genes between the two groups of patients or in the two hospitals. Regarding the virulence genes, there was statistically significant difference when comparing the two hospitals.
\end{abstract}

Keywords: Staphylococcus; Antibiotic resistance; Oncology; Virulence. 


\begin{abstract}
Resumo
Staphylococcus spp. é uma das principais bactérias associadas a infecções na área de saúde, especialmente em unidades de terapia intensiva, e uma das principais causas de complicações em pacientes com câncer. Este estudo comparou o perfil de susceptibilidade aos antimicrobianos e a frequência de genes de resistência (mecA, blaZ, ermA e erm $\mathrm{C}$ ) e virulência (ica $\mathrm{A}$, icaD e hlg) em Staphylococcus spp. de pacientes de um Hospital Oncológico $(\mathrm{OH})$ e Hospital Universitário (HU). O tipo de complexo $\mathrm{ccr}$ foi avaliado por PCR entre os isolados mecA positivos do HU. Maior porcentagem de isolados suscetíveis, exceto para oxacilina e cefoxitina, foi encontrada entre os isolados de UH e $27,3 \%$ dos isolados resistentes à vancomicina foram identificados através método de screening; 41 isolados exibiram o fenótipo MLSBc e cinco o fenótipo MSLBi, e um isolado do $\mathrm{OH}$ do fenótipo constitutivo exibiu o gene erm C. Os $c c r$ tipos I e II foram identificados, sendo maior frequência do $c c r$ tipo I. Não foi encontrada diferença estatisticamente significativa na frequência dos genes entre os dois grupos de pacientes ou nos dois hospitais. Em relação aos genes de virulência, houve diferença estatisticamente significativa na comparação dos dois hospitais.
\end{abstract}

Palavras-chave: Staphylococcus; Resistência a antibióticos; Oncologia; Virulência.

\title{
Resumen
}

Staphylococcus spp. es una de las principales bacterias asociadas a las infecciones en la asistencia sanitaria, especialmente en las unidades de cuidados intensivos, y una de las principales causas de complicaciones en los pacientes oncológicos. Este estudio comparó el perfil de susceptibilidad antimicrobiana y la frecuencia de genes de resistencia (mecA, blaZ, ermA y erm $\mathrm{C}$ ) y virulencia (icaA, icaD y hlg) en Staphylococcus spp. de pacientes de un Hospital Oncológico $(\mathrm{OH})$ y Hospital Universitario (HU). El tipo de complejo $c c r$ se evaluó mediante PCR entre los aislados mecA positivos de la HU. Se encontró un mayor porcentaje de aislados susceptibles, a excepción de oxacilina y cefoxitina, entre los aislados de UH y el 27,3\% de los aislados resistentes a la vancomicina se identificaron mediante el método de cribado; 41 aislamientos exhibieron el fenotipo MLSBc y cinco el fenotipo MSLBi, y un aislado OH del fenotipo constitutivo exhibió el gen ermC. Se identificaron CCR tipo I y tipo II, con mayor frecuencia de CCR tipo I. No hubo diferencia estadísticamente significativa en la frecuencia genética entre los dos grupos de pacientes o en los dos hospitales. En cuanto a los genes de virulencia, hubo una diferencia estadísticamente significativa al comparar los dos hospitales.

Palabras clave: Staphylococcus; Resistencia antibiótica; Oncología; Virulencia.

\section{Introduction}

Bacterial infections are a major cause of complications in patients with hematological neoplasia and chemotherapyinduced neutropenia and bacteremia is the leading cause of death, either directly or by interfering with the chemotherapy chronogram (Montassier, et al., 2013; Quiles et., al, 2015; Jiang et al., 2020). Risk factors for infection in this group of patients are more expressive, because the immunocompromised related by disease itself, they are subjected to surgical treatment, chemotherapy and/or radiotherapy, where neutropenia is a major risk for infection in this population (Jiang et al., 2020).

In recent decades, the success of the treatment of malignancies in children and teenagers has increased, with up to 70 $-80 \%$ of cases. Furthermore, the immunosuppression from the treatment makes these patients more susceptible to infections, which are the main cause of death among them. In these patients, bacteremia often results from infection by one or more microorganisms, mainly members of the Enterobacteriaceae family, Pseudomonas aeruginosa, Streptococcus and Staphylococcus (Quiles et., al, 2015). Over the last three decades, the proportion of Gram-positive microorganisms has increased because of the widespread use of permanent catheters (Montassier, et al., 2013).

It is noteworthy that the intensive care centers concentrate the highest incidence rates of hospital infections, and are emergency epicenters of microbial resistance, due to the hospitalization of seriously ill patients. These patients, in most cases, use a wide spectrum antimicrobials and are subjected to successive invasive procedures (Jiang et al., 2020). Occur more and more evidences supports the idea that neutropenic patients at low risk do not necessarily need hospitalization and antibiotic wide spectrum prolonged to bacterial invasive infections. The strategies for this group include antimicrobial short-term treatment with a consequent reduction in hospitalization and outpatient management with the use of oral antibiotics (Cagol et al., 2009), reinforcing the importance of proper characterization of the resistance profiles of bacterial strains.

S. aureus can evade the host immune system due to the existence of several virulence factors and some studies have shown differences in the production of virulence factors such as gamma-hemolysin ( $h l g$ ) and biofilm (ica) between the strains 
isolated from different clinical specimens (Kord et al., 2018; Elboshra et al., 2020). However, these comparisons have not been related described in patients of oncology centers. The biofilm production may allow these isolates colonize the catheter and other devices, to evading the immune system and microorganisms might lead to an increased frequency of bacteremia and false-positive or false-negative blood cultures (Figueiredo et al., 2017; Kord et al., 2018).

In a retrospective study in an U.S., oncology hospital it was determined the existence of clones among isolates resistant groups related with the resistance data associated with clinical information suggestive of infection (Muldrew et al., 2008).

Among the several resistance mechanisms of Staphylococcus, the most common are the resistance to macrolides, aminoglycosides, beta-lactams and glycopeptides (Sangappa \& Thiagarajan, 2012; Jenkins et al., 2015). The importance of these microorganisms depends on the toxins mediated virulence, its invasive nature and its antibiotics resistance profile (Jenkins et al., 2015; Elboshra et al., 2020). These characteristics are related to the diversity of clinical manifestations (Lim et al., 2012; Jenkins et al., 2015), however concerning the oncology patients, this is not yet clear.

The increasing of resistant strains with different virulence factors over the years indicates the potential failure of the use of antimicrobials in the treatment of infections due to the association of the resistance mechanisms of the microorganism and the resistance of the host immune response (Lim et al., 2012). The number of virulence associated genes harbored by a bacterial isolate results from the interaction between gene acquisition rates, the biological maintenance cost and the failure rate of the disease (Leclercq, 2002; Jenkins et al., 2015). Thus, the more severe S. aureus infections cannot be explained by the action of a certain virulence fator only, but rather by the action of several virulence factors during the infectious process. The survival and proliferation of a certain pathogen in the host is favored by mechanisms that enable evasion of the host immune mechanisms. Thus, strains that escape more efficiently the host defense mechanisms are the most prevalent. There is evidence that some clonal types are more virulent than others and they occur more frequently among patients than in healthy individuals (Leclercq, 2002; Spaan et al., 2014).

The proposal of this study was to characterize and comparing Staphylococcus spp. isolates from oncologic and nononcologic patients of two hospitals in the city of Recife-PE, regarding antimicrobials susceptibility profile, and the resistance and virulence genes content. This microbiological analysis will allow mapping the bacterial strains through resistance and virulence factors, which will facilitate tracing rational use of antimicrobials and treatment of the infections in the hospitals.

\section{Methodology}

The observacional study (Fontelles et al., 2009) compared Staphylococcus spp. isolates from oncological and nononcological patients from an oncology $(\mathrm{OH})$ and a university hospital (UH) respectively in Recife, PE, Brazil during one year (2013) period. In the study, patients of male and female gender were included. The samples were collected during routine by the medical and nursing staff of the hospitals. The isolates were identified by macroscopic characteristics on 5\% blood agar plates, Gram staining and the catalase, coagulase, DNAse and Mannitol salt agar tests (CLSI, 2014).

\section{Antimicrobial Susceptibility.}

Staphylococcus isolates were tested by the disk diffusion technique in Mueller-Hinton Agar (CLSI, 2014) plates using the following antimicrobials and concentrations: penicillin $10 \mathrm{U}$, oxacillin $1 \mu \mathrm{g}$, vancomycin $30 \mu \mathrm{g}$, gentamicin $10 \mu \mathrm{g}$, clindamycin $2 \mu \mathrm{g}$, sulfamethoxazole-trimethropim $1.25 / 23.75 \mu \mathrm{g}$, ciprofloxacin $5 \mu \mathrm{g}$, cefoxitin $30 \mu \mathrm{g}$, teicoplanin $30 \mu \mathrm{g}$, erytromycin $15 \mu \mathrm{g}$ e tetracyclin $30 \mu \mathrm{g}$. The Clinical and Laboratory Standards Institute (CLSI) interpretive breakpoints were considered (CLSI, 2014). The erythromycin and clindamycin disks were placed approximate to assess the induced resistance (D test) (CLSI, 2014). 


\section{Screening of Oxacillin}

Subcultures were made in nutrient agar plates of the isolates that were resistant to oxacillin and/or cefoxitin in disk diffusion technique. It was made direct suspension of colonies to obtain a turbidity to a standard solution of 0.5 McFarland scale. Was dipped into a $1 \mu \mathrm{L}$ inoculation loop in this suspension and proceeding with the inoculum in area with a diameter of 10 to $15 \mathrm{~mm}$ on plates containing Mueller Hinton agar medium with $\mathrm{NaCl}(4 \% \mathrm{v} / \mathrm{v}, 0.68 \mathrm{~mol} / \mathrm{L}$ ) and $6 \mu \mathrm{g} / \mathrm{mL}$ of oxacillin. These plates were incubated at $35{ }^{\circ} \mathrm{C}$ for 24 hours being considered, after reading the results as: $>1$ colony $=$ resistant. Were used as quality control standard strains for MRSA and MSSA: Staphylococcus aureus ATCC 29213 - Sensitive and Staphylococcus aureus ATCC 33591 - Resistant (CLSI, 2014).

\section{Vancomycin Screening}

All isolates were subjected to screening of vancomycin. These samples were inoculated into BHI broth and incubated at $35^{\circ} \mathrm{C}$ to reach a $2 \mathrm{McFarland}$ turbidity scale. One $1 \mu \mathrm{L}$ loop of this grow was spread in area of 10 to $15 \mathrm{~mm}$ diameter on plates containing BHI agar supplemented with $6 \mu \mathrm{g} / \mathrm{mL}$ of vancomycin (OXOID) and incubated at $35{ }^{\circ} \mathrm{C}$ for 24 and 48 hours considering resistance as > 1 colony (Burnham, Weber \& Dunne Jr, 2010; CLSI, 2014).

Enterococcus faecalis ATCC 29212 - Sensitive e Enterococcus faecalis ATCC 51299 - Resistant were used as quality control standard strains (CLSI, 2014).

\section{Total DNA Extraction}

Total DNA was extracted from the isolates following Oliveira et al (2015) and the DNA obtained was quantified using nanodrop 2000 (Thermo Scientific).

\section{Identification of the mecA gene by PCR}

The presence of the mecA gene was assessed by PCR among the oxacillin and/or cefoxitin phenotypically resistant isolates using the primers described by Oliveira et al (2015). The PCR reactions were individually prepared in a final volume of $25 \mu \mathrm{L}$ containing: $20 \mathrm{ng}$ of genomic DNA, 20pmol of each primer, $\mathrm{MgCl}_{2} 1,5 \mathrm{mM}$, dNTP $200 \mu \mathrm{M}$, $1 \mathrm{U}$ of Go Taq DNA polimerase (Promega, Brasil) and $5 \mu \mathrm{L}$ of Green Go Taq DNA polimerase buffer (Promega, Brasil). The reactions were performed in a thermocycler (Biometra), set for 35 cycles of one minute at $94^{\circ} \mathrm{C}$, one minute at $55^{\circ} \mathrm{C}$ and two minutes at $72^{\circ} \mathrm{C}$ followed by a final-step of 15 minutes at $72^{\circ} \mathrm{C}$. As negative control, a tube containing all the components of the mixture without DNA and for positive control DNA from the strain Staphylococcus aureus ATCC 33591 - Resistant were used.

\section{Identification of the beta - lactamase gene (blaZ) by PCR}

The presence of the blaZ gene was assessed by PCR among the oxacilin and/or cefoxitin phenotypically resistant isolates using the primers described by Milheiriço et al (2011). The PCR reactions were individually prepared in a final volume of $25 \mu \mathrm{L}$ containing: $20 \mathrm{ng}$ of genomic DNA, 20pmol of each primer, $2,5 \mu \mathrm{L}$ of $\mathrm{MgCl}_{2}(25 \mathrm{mM}), 2,5 \mu \mathrm{L}$ dNTP $(200 \mu \mathrm{M}), 1 \mathrm{U}$ of Go Taq DNA polimerase (Promega, Brasil) and $5 \mu \mathrm{L}$ of Green Go Taq DNA polimerase buffer (Promega, Brasil). The reactions were performed in a thermocycler (Biometra), set for 30 cycles composed of one minute at $92^{\circ} \mathrm{C}$, one minute at $55^{\circ} \mathrm{C}$ and two minutes at $72^{\circ} \mathrm{C}$ followed by a final step of seven minutes ate $72^{\circ} \mathrm{C}$. A tube containing all the components of the mixture without DNA was used as negative control and DNA from the isolate code 1171 from the Culture Collection from the Microbiology Departament from the FIOCRUZ-PE, positive for the gene blaZ confirmed by sequencing, was used as positive control. 


\section{Determining the type of SCCmec}

The type of the $c c r$ complex was assessed by multiplex PCR among the mecA positive isolates from the UH following a protocol based on Kondo et al (2007) as follows: PCR reactions were individually prepared in a final volume of $50 \mu \mathrm{L}$ containing: 20ng of genomic DNA, $10 \mu \mathrm{M}$ of each primer, $6,4 \mu \mathrm{L}$ of $\mathrm{MgCl}_{2}(25 \mathrm{mM}), 4,0 \mu \mathrm{L}$ dNTP $(2,5 \mathrm{mM}), 1 \mathrm{U}$ of Go Taq DNA polimerase (Promega, Brasil) and $5 \mu \mathrm{L}$ of Green Go Taq DNA polimerase buffer (Promega, Brasil). The primers used are described in Table 1 and the PCR products are described in Chart 1 . The reactions were performed in a termocycler (Biometra), programmed for 30 cycles composed of one minute at $95^{\circ} \mathrm{C}$, one minute at $57^{\circ} \mathrm{C}$ and two minutes at $72^{\circ} \mathrm{C}$ followed by a step of seven minutes at $72^{\circ} \mathrm{C}$.

Table 1: Primer sequence to be used for multiplex PCR reactions to determine the ccr complex (Kondo et al., 2007).

\begin{tabular}{cc}
\hline Primer & Sequences (5'-3') \\
\hline$\alpha_{1}$ & 5'AACCTATATCATCAATCAGTACGT3' \\
$\alpha_{2}$ & 5'TAAAGGCATCAATGCACAAACACT3' \\
$\alpha_{3}$ & 5'AGCTCAAAAGCAAGCAATAGAAT3' \\
$\beta_{c}$ & 5'ATTGCCTTGATAATAGCCITCT3' \\
MA1 & 5'TGCTATCCACCCTCAAACAGG3' \\
MA2 & 5'AACGTTGTAACCACCCCAAGA3' \\
$\gamma F$ & 5'CGTCTATTACAAGATGTTAAGGATAA \\
$\gamma R$ & 5'CCTTTATAGACTGGATTATTCAAAAT \\
\end{tabular}

Source: Authors.

Chart 1: PCR products on 2\% agarose gel

\begin{tabular}{|l|c|}
\hline ccr complex 1 & $695 \mathrm{bp}$ \\
\hline ccr complex 2 & $937 \mathrm{bp}$ \\
\hline ccr complex 3 & $1791 \mathrm{bp}$ \\
\hline ccr complex 5 & $518 \mathrm{bp}$ \\
\hline
\end{tabular}

Source: Authors.

\section{Detection of erm A and erm $\mathrm{C}$ genes by PCR technique}

The isolates erythromycin and clindamycin resistant (phenotype $\mathrm{MLSB}_{\mathrm{c}}$ ) and erytromycin positive in the D test (phenotype $\mathrm{MLSB}_{\mathrm{i}}$ ) were analysed for the presence of the ermA and $\operatorname{ermC}$ genes using the primers described by Lina et al (1999a): ermA F5'GTTCAAGAACAATCAATACAGAG3' and R5'GGATCAGGAAAAGGACATTTTAC3'; ermC: F5'GCTAATATTGTTTAAATCGTCAATTCC3' and R5'GGATCAGGAAAAGGACATTTTAC3'. For the detection of ermA the amplification reaction was prepared in a final volume of $25 \mu 1$ for tube including: $1 \mu 1$ (40ng) of total DNA, $1 \mu 1$ (20pmol) of each primer, $0,6 \mu 1$ of deoxyribonucleotide triphosphate (dNTP) $(8 \mathrm{mM}), 5,0 \mu 1$ of buffer $(5 \mathrm{x}), 1,5 \mu \mathrm{l}$ of $\mathrm{MgCl}_{2}(25$

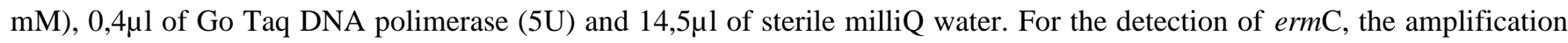
reaction was prepared as above, except for using $0,3 \mu 1$ (5U) of Go Taq DNA polimerase and 14,6 $\mu$ l sterile milliQ water. Amplification reactions were performed in a thermocycler under the following conditions: 30 cycles of one minute at $94^{\circ} \mathrm{C}, 30$ 
seconds at $49^{\circ} \mathrm{C}$, and 30 seconds at $72^{\circ} \mathrm{C}$. As negative control a tube containing all the components of the mixture without DNA and as positive control DNA from one isolate positive for the genes (ermA and ermC) confirmed by amplification and sequencing were used.

\section{Detection of the ica A and icaD genes}

The amplification of the ica $\mathrm{A}$ and $i c a \mathrm{D}$ genes from the operon ica $\mathrm{ADBC}$, was performed using the primers described by Vasudevan et al (2003) (F5'CCTAACTAACGAAAGGTAG3' and R5'GGCAATATGATCAAGATAC3') for of a 1.585bp amplification. PCR reactions were individually prepared in a final volume of $25 \mu \mathrm{L}$, containing: 20ng of genomic DNA, 20pmol of each primer, $1,75 \mu \mathrm{L}$ of $\mathrm{MgCl}_{2}(25 \mathrm{mM}), 0,63 \mu \mathrm{L} \mathrm{dNTP}(8 \mathrm{mM}), 1 \mathrm{U}$ of Go Taq DNA polimerase (Promega, Brasil) and $5 \mu \mathrm{L}$ of Green Go Taq DNA polimerase buffer (Promega, Brasil). The reactions were performed in a thermocycler (Biometra), programmed for 30 cycles of one minute at $94^{\circ} \mathrm{C}$, one minute at $50^{\circ} \mathrm{C}$ and one minute at $72^{\circ} \mathrm{C}$ followed by 15 minutes at $72^{\circ} \mathrm{C}$. As negative control a tube containing all the components of the mixture without DNA and as positive control the DNA from the isolate code 047 from the Culture Collection from the Microbiology Departament from the FIOCRUZ-PE, positive for the genes confirmed by sequencing, was used as positive control.

\section{Detection of the $h l g$ gene}

For amplification of the $h l g$ gene the protocol described by Lina et al (1999b) was employed using the primers F5'GCCAATCCGTTATTAGAAAATGC3' and R5'CCATAGACGTAGCAACGGAT3' for a 937bp fragment. PCR reactions were individually prepared in a final volume of $25 \mu \mathrm{L}$ containing: $20 \mathrm{ng}$ of genomic DNA, 20 pmol of each primer, $1,75 \mu \mathrm{L}$ of $\mathrm{MgCl}_{2}(25 \mathrm{mM}), 0,63 \mu \mathrm{L}$ dNTP $(8 \mathrm{mM}), 1 \mathrm{U}$ of Go Taq DNA polimerase (Promega, Brasil) and $5 \mu \mathrm{L}$ of Green Go Taq DNA polimerase buffer (Promega, Brasil). The amplification reaction was programmed for 30 cycles composed of one minute at $94^{\circ} \mathrm{C}$, one minute at $50^{\circ} \mathrm{C}$ one minute at $72^{\circ} \mathrm{C}$ followed by 15 minutes at $72^{\circ} \mathrm{C}$. As negative control, a tube containing all the components of the mixture without DNA and as positive control the DNA from the isolate code 412 from the Culture Collection from the Microbiology Departament from the FIOCRUZ-PE, positive for the gene $h l g$ confirmed by sequencing, was used.

The products of all amplifications were electrophoresed in $1 \%$ agarose gels, stained with Blue-Green (LGC Biotechnology), visualized in UV transilluminator and scanned by Kodak 1D software version 3.5.2 (Scientific Imaging Systems, USA). For the products of the $c c r$ complex amplification $2 \%$ agarose gels were used. The molecular weight marker 100bp DNA ladder (Invitrogen) was used.

\section{Data Analysis}

Clinical and microbiological data were introduced in SPSS Statistics 20 software for statistical analysis through frequency distribution, $x^{2}$ test and Fisher's Test.

\section{Results}

Total of 173 isolates (104 S. aureus and 69 CoNS) were obtained, 51 (47 S. aureus and 4 CoNS) from patients of the $\mathrm{OH}$ and 122 (57 S. aureus and 65 CoNS) from patients of the UH in Recife, PE, Brazil were obtained during the year 2013. The more frequent source of the samples was blood culture, followed by catheter tip in both hospitals (Table 2). 
Table 2: Distribution of Staphylococcus spp. isolates from the samples and hospital origin.

\begin{tabular}{|c|c|c|c|}
\hline Sample type & UH & $\mathrm{OH}$ & TOTAL \\
\hline Blood & 41 & 13 & 54 \\
\hline Catheter tip & 21 & 7 & 28 \\
\hline Peritoneal fluid & 1 & 1 & 2 \\
\hline $\begin{array}{l}\text { Tracheal } \\
\text { aspirates }\end{array}$ & 16 & 6 & 22 \\
\hline Wounds & 7 & 3 & 10 \\
\hline $\begin{array}{l}\text { Diverse } \\
\text { secretions }\end{array}$ & 16 & 12 & 28 \\
\hline Urine & 4 & 2 & 6 \\
\hline Fist tumor & 0 & 1 & 1 \\
\hline Ascites fluid & 1 & 2 & 3 \\
\hline Tissue fragment & 6 & 1 & 7 \\
\hline Chest wall & 0 & 1 & 1 \\
\hline Abscess & 4 & 2 & 6 \\
\hline Sperm & 1 & 0 & 1 \\
\hline LCR & 3 & 0 & 3 \\
\hline $\begin{array}{l}\text { Bronchoalveolar } \\
\text { lavage }\end{array}$ & 1 & 0 & 1 \\
\hline TOTAL & 122 & 51 & 173 \\
\hline
\end{tabular}

Source: Authors.

Related with the antimicrobial profile there was a higher percentage of susceptible isolates, except for oxacillin and cefoxitin among the 122 isolates from the UH (Table 3). 54 (51.9\%) isolates were resistant in the screening spot of oxacillin, however, observing each hospital, the UH has $54.8 \%$ (46/84) of resistant isolates and $\mathrm{OH} 40 \%(8 / 20)$. 24 (27.3\%) isolates were resistant vancomycin screening spot (Table 4). 
Table 3: Antimicrobial susceptibility of Staphylococcus spp. isolates in University and Oncologic Hospitals.

\begin{tabular}{lcccc}
\hline \multicolumn{1}{c}{ Antimicrobial } & \multicolumn{2}{c}{ UH } & \multicolumn{2}{c}{ OH } \\
& Sensitive & Resistant & Sensitive & $\begin{array}{c}\text { Resista } \\
\text { nt }\end{array}$ \\
\hline Oxacillin & 54 & 68 & 40 & 11 \\
Cefoxitin & 43 & 79 & 39 & 12 \\
Vancomycin & 120 & 2 & 51 & 0 \\
Teicoplanin & 118 & 4 & 43 & 8 \\
Gentamicin & 71 & 51 & 45 & 6 \\
Erytromycin & 54 & 68 & 33 & 18 \\
$\begin{array}{l}\text { Clindamycin } \\
\text { Tetracyclin }\end{array}$ & 66 & 56 & 43 & 8 \\
$\begin{array}{l}\text { Sufamethoxazole/ } \\
\text { trimethropim }\end{array}$ & 84 & 38 & 41 & 10 \\
Ciprofloxacin & 107 & 15 & 49 & 2 \\
\hline
\end{tabular}

Source: Authors.

Table 4: Antimicrobial susceptibility to Oxacillin and Vancomycin of Staphylococcus spp. isolates in University and Oncologic Hospitals.

\begin{tabular}{llccc}
\hline Screening type & Test & \multicolumn{2}{c}{ Hospital } & Total \\
& Results & UH & OH & \\
\hline Oxacillin & Resistant & 46 & 8 & 54 \\
& Sensitive & 38 & 12 & 50 \\
& Total & 84 & 20 & 104 \\
Vancomycin & Resistant & 11 & 13 & 24 \\
& Sensitive & 33 & 31 & 64 \\
& Total & 44 & 44 & 88 \\
\hline
\end{tabular}

Source: Authors.

The occurrence of the blaZ and mecA genes was assessed by PCR among the methicillin and cefoxitin and/or oxacillin phenotypically resistant isolates. Among these from the Oncology Hospital $50 \%$ and $77.7 \%$, respectively were positive for the blaZ and mecA genes (Table 5). The isolates analyzed from the University Hospital $45.7 \%$ were positive for the blaZ gene and $17 \%$ for the mecA gene (Table 5). 
Table 5: Results of PCR for blaZ, mecA, icaAD and hlg genes for the two hospitals.

\begin{tabular}{lccc}
\hline \multirow{2}{*}{ PCR type } & Results & \multicolumn{2}{c}{ Hospital } \\
& & UH & OH \\
\hline \multirow{2}{*}{ blaZ } & Positive & 16 & 9 \\
& Negative & 19 & 9 \\
mecA & Positive & 8 & 14 \\
& Negative & 39 & 4 \\
icaAD & Positive & 3 & 9 \\
& Negative & 9 & 19 \\
hlg & Positive & 6 & 14 \\
& Negative & 8 & 6 \\
\hline
\end{tabular}

Source: Authors.

Related another antimicrobial, the profile of susceptibility to erythromycin and clindamycin was also analyzed through the disk diffusion method, 41 isolates with MLSB $_{c}$ phenotype (Macrolides, Lincosamides and Streptogramis constituent B) and five MSLB $_{i}$ phenotype (Macrolides, Lincosamides and Streptogramis inducible B) were identified at the University Hospital. In the Oncology Hospital, eight isolates were identified with the phenotype MLSB and and six MLSB $_{i}$ (Table 6).

Table 6: Results of PCR for ermA and ermC genes for the two hospitals.

\begin{tabular}{|c|c|c|c|c|c|c|c|c|}
\hline \multirow{4}{*}{ Hospital } & \multicolumn{8}{|c|}{ Phenotype } \\
\hline & \multicolumn{4}{|c|}{$\mathrm{MLSB}_{\mathrm{c}}$} & \multicolumn{4}{|c|}{$\mathrm{MLSB}_{\mathrm{i}}$} \\
\hline & ermA & ermA & ermC & ermC & ermA & ermA & erm C & ermC \\
\hline & positive & negative & positive & negative & positive & negative & positive & negative \\
\hline $\mathrm{UH}$ & 5 & 36 & 16 & 25 & 0 & 5 & 1 & 4 \\
\hline $\mathrm{OH}$ & 0 & 8 & 1 & 7 & 0 & 6 & 0 & 6 \\
\hline
\end{tabular}

Source: Authors.

The isolates displaying the phenotypes $\mathrm{MLSB}_{\mathrm{c}}$ and $\mathrm{MLSB}_{\mathrm{i}}$ were analyzed by PCR for the detection of the ermA and erm $\mathrm{C}$ genes. Only one isolate was found harboring the constitutive phenotype erm $\mathrm{C}$ gene. The erm $\mathrm{A}$ gene wasn't observed in Oncology hospital (Table 6). It was observed positive isolates for all genes in the studied phenotypes, except for the ermA gene in induced phenotype in the University Hospital (Table 6).

The occurrence of the genes icaAD and $h l g$ was observed respectively in $25 \%$ and $42.8 \%$ in the isolates from the University Hospital and in $32.1 \%$ and $70 \%$ respectively in the isolates from the Oncology Hospital. Table 5 shows the distribution according to the source of origin.

In this study, there was no statistically significant difference in the occurrence of the resistance genes blaZ, mecA, erm $\mathrm{A}$ and erm $\mathrm{C}$ when compairing the two hospitals. Regarding the virulence genes, there was statistically significant difference when comparing the two hospitals. Chart 2 and 3 shows the results of the $p$ value found in the static analysis.

Out of the five mecA positive isolates from the University Hospital analyzed by PCR for determination of the $c c r$ complex type, four showed Type I ccr (ccrA1, 695bp) and one was Type II (ccrA2, 937 bp). 
Chart 2: Results fot the $p$ values for comparisons between the PCR of resistance genes for the two hospitals.

\begin{tabular}{|c|c|c|c|c|c|c|c|c|}
\hline \multicolumn{4}{|c|}{ ACR bisz } & \multicolumn{5}{|c|}{ PCR mecA } \\
\hline \multicolumn{4}{|c|}{ Con-Sosare Teats } & \multicolumn{5}{|c|}{ CN-Soure Testh } \\
\hline & Value & Dt & $\begin{array}{l}\text { Aspmp.Sig } \\
\text { (2-aided) }\end{array}$ & & vatere & 마 & \multicolumn{2}{|c|}{$\begin{array}{l}\text { Asymp. } \operatorname{sig}(2- \\
\text { sided) }\end{array}$} \\
\hline $\begin{array}{l}\text { Fearsonchi: } \\
\text { Square }\end{array}$ & 6,1200 & 2 & 047 & $\begin{array}{l}\text { PearsonChi- } \\
\text { Soyare. }\end{array}$ & 27.421. & 2 & & .006 \\
\hline Luelhood Rlaso & 6270 & 2 & .045 & LakplinoodRaso & 30,998 & 2 & & 90 \\
\hline Nof Valld Cases & 113 & & & Not Valid Taaes & 125 & & & \\
\hline \multicolumn{4}{|c|}{ 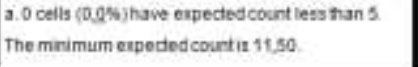 } & \multicolumn{5}{|c|}{ 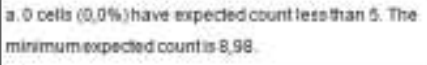 } \\
\hline \multicolumn{4}{|c|}{ PCR 5 rma } & \multicolumn{5}{|c|}{ PCH exmC } \\
\hline \multicolumn{4}{|c|}{ Crisquare Tests } & \multicolumn{5}{|c|}{ consquare Testa } \\
\hline & vatue & of & $\begin{array}{c}\text { Asymp seg } 52- \\
\text { siosed }\end{array}$ & & & vatse & Df & $\begin{array}{l}\text { Asymp Silg } \\
\text { 42 sised }\end{array}$ \\
\hline $\begin{array}{l}\text { Foarsonchi: } \\
\text { square }\end{array}$ & s.,0ses & 2 & .017 & \multicolumn{2}{|l|}{ pearson Chl-5quare } & $10: 147^{*}$ & -2 & .006 \\
\hline UKernoggRaso & 9763 & 2 & .008 & \multicolumn{2}{|l|}{ Withoot Ratio } & 12,096 & 2 & .002 \\
\hline Nor Vald Cases & $\$ 41$ & & & \multicolumn{2}{|l|}{ Nof VatuCases } & 140 & & \\
\hline \multicolumn{4}{|c|}{$\begin{array}{l}\text { a. } 2 \text { ceis }(33,3 \text { as) have expected courtiess than } 1 \\
\text { The minimum expedod countis } 1,00 \text {. }\end{array}$} & \multicolumn{5}{|c|}{$\begin{array}{l}\text { 2. D cells } 10,0 \% \text {; have expeciod court less fran I The } \\
\text { minimurnexpectad countis } 5,9 \text { ? }\end{array}$} \\
\hline
\end{tabular}

Source: Authors.
Chart 3: Results for the $p$ values for comparisons between the PCR of virulence genes for the two hospitals.

\begin{tabular}{|c|c|c|c|c|c|}
\hline \multicolumn{6}{|c|}{ DCLIEAAR } \\
\hline \multicolumn{6}{|c|}{ Onseure Tenth } \\
\hline & vases & $a$ & $\begin{array}{c}\text { Anne Do R } \\
\text { shose }\end{array}$ & $\begin{array}{c}\text { Ford pe If } \\
\text { nosd }\end{array}$ & $\begin{array}{c}\text { Eusteg of } \\
\text { nowal }\end{array}$ \\
\hline Rearuat ckisquan & $234^{\circ}$ & 1 & ent & & \\
\hline Contriap convedont & ase & 1 & 9906 & & \\
\hline Unethoot Rnis & 290 & 1 & 548 & & \\
\hline Fataristeas feil & & & & mas & ath \\
\hline Natvancan: & $4=$ & & & & \\
\hline \multicolumn{6}{|c|}{ 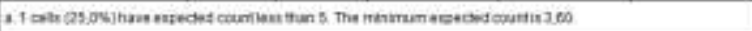 } \\
\hline \multicolumn{6}{|c|}{ 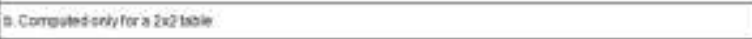 } \\
\hline \multicolumn{6}{|c|}{ PCreting } \\
\hline \multicolumn{6}{|c|}{ Carsavo Ten } \\
\hline & vase & a & 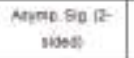 & $\begin{array}{c}\text { Exodgo iz- } \\
\text { nsedi }\end{array}$ & $\begin{array}{c}\text { Eurtsig it. } \\
\text { noedi }\end{array}$ \\
\hline Pearuatchisgais & $23 n 0$ & 1 & $\sin$ & & \\
\hline Canthesy consaset & 1510 & 1 & 211 & & \\
\hline Latioosknos & 2514 & 1 & .71 & & \\
\hline Fateristoses teat & & & & .165 & 10 \\
\hline Matveidcases: & 34 & & & & \\
\hline \multicolumn{6}{|c|}{ 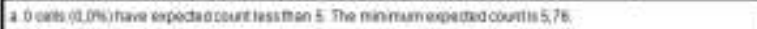 } \\
\hline
\end{tabular}

Source: Authors.

\section{Discussion}

Most Staphylococcus spp. carriers are asymptomatic and related the process of infection is usually associated with some factor which decreases the immune response of the individual, as invasive medical procedures, being this microorganism referred to as a main agents of bacteremia, often acquired in hospital environment (Muldrew et al., 2008). Among the users of central vascular catheter, S. aureus and CoNS are the more frequent microorganisms, accounting for $30 \%$ of the isolates (Muldrew et al., 2008 Montassier, et al., 2013) in our study, the most frequent samples were blood culture and catheter tip with percentages of respectively $33,6 \%$ and $17,2 \%$ for the $\mathrm{UH}$ and $25,5 \%$ and $13,7 \%$ for $\mathrm{OH}$, similar a study in public hospital in Brazil (Bride et al., 2019).

The frequency of isolation of $S$. aureus and its relationship with hospital infections reach high values in many Brazilian hospitals, related of prevalence of MRSA strains varies from 40 to 80\% (Lina et al., 1999b; Jones et al., 2013; Bride et al., 2019) and data from the Antimicrobial Surveillance Program show that MRSA reached 31\% among the nosocomial and communitarian infections agents and are considered the more common among the most prevalent pathogens (Jones et al., 2013; Silveira et al., 2015). A survey in Brazilian hospitals showed 80\% (Silveira et al., 2015) resistance of CoNS in blood cultures. In our study, this was the most frequent type of sample; however, S. aureus was more prevalent in both hospitals.

Concerning the detection of the genes blaZ and mecA by PCR 50\% and $77.7 \%$ of positive samples were found respectively in the $\mathrm{OH}$ while in the $\mathrm{UH}$ there was $45.7 \%$ of occurrence for the blaZ gene and $7 \%$ for the mecA gene. Some studies show that the rate of beta-lactamase production ranges from $55.7 \%$ to $92.6 \%$ for Staphylococcus (Oliveira et al., 2011; Rabelo et al., 2013) and our results fit within these limits. Oliveira et al (2011) found high prevalence of beta-lactamase in their 
isolates $(83 \%)$ and they drew attention to the widespread use of drugs in the clinical practice which may trigger resistance to several antimicrobial classes.

A study in India by Prabhash et al (2010) reported a rate of $18 \%$ of methicillin-resistant S. aureus from cancer patients, similar to our results in the University Hospital in Recife. Another study conducted in South Korea by Kang et al (2012), reported a prevalence of $48.4 \%$ of MRSA associated with bacteremia in cancer patients, a percentage lower than that from our work $(77.7 \%)$ for oncology patients.

Another study conducted earlier in the same University Hospital, reported percentage slightly lower than ours, about $10 \%$ of the isolates were considered MRSA (Rabelo et al., 2014), suggesting that the control measures of this type of microorganism have not been fully effective. In this study, was noted the presence of strains resistant to methicillin only by phenotype methods for both hospitals, suggests the presence of other mechanisms of resistance or non - expression of genes researched (Sangappa \&Thiagarajan, 2012; Milheiriço et al., 2011; Andrade-Figueiredo \& Leal-Balbino, 2016).

The profile of resistance to vancomycin in the present study among the isolates from the University and Oncology Hospitals described the percentage rate of $25 \%$ and $29.5 \%$ respectively. Staphylococci resistant to glycopeptides were described in Brazil, and isolation of vancomycin resistant S. aureus registered in São Paulo (Rossi et al, 2014; Panesso et al, 2015). Other study previously conducted in the University Hospital (Rabelo et al., 2014), reported 11\% of resistant isolates using the screening spot method, but only among MRSA samples and the same hospital vanA gene was detected of isolates of S. epidermidis from nasopharyngeal secretion of health care workers (Bezerra Neto et al., 2018).

In the present study, the $\mathrm{MLSB}_{\mathrm{c}}$ phenotype found in 41 isolates (33.6\%) from the University Hospital and eight isolates (15.7\%) from the Oncology Hospital was predominant over the MLSB ${ }_{i}$ phenotype found in five isolates (4.1\%) from the University and six isolates (11.8\%) from the Oncology Hospital. These findings are different from those from another study in Brazil that identified 71 (46.7\%) MLSB ${ }_{c}$ and five $\operatorname{MLSB}_{\mathrm{i}}$ (3.3\%) isolates (Coutinho et al., 2010).

Antimicrobial susceptibility data are essential for appropriate therapy making imperative to perform the $\mathrm{D}$ test (Coutinho et al., 2010; Juyal et al., 2013). Categorizing a Staphylococcus spp. isolate as clindamycin sensitive without verifying if there is inducible resistance may result inadequate therapy. On the other hand, a negative result for inducible clindamycin resistance confirms the antimicrobial sensitivity and allow a correct therapeutic (Kumar et al., 2012).

Two studies conducted in Iran related with erythromycin-resistant genes described the frequency of erm $\mathrm{C} 35.2 \%$ and ermA 20.4\% (Sedaghat et al., 2017) and Saderi, Emadi and Owlia (2011), found the opposite, the ermA gene was more frequent than the $\mathrm{erm} \mathrm{C}$ gene, 76 (60.3\%) and 69 (54.8\%) respectively among the S. aureus isolates. Different results were obtained in our study, the presence of the erm $\mathrm{C}$ gene was higher than the erm $\mathrm{A}$ gene in the isolates of both Hospitals. In our study, no single positive isolate was found for the ermA gene in Oncology Hospital for the studied phenotypes. No single positive isolate was found for the induced phenotype at the University Hospital. The isolates that do not harbor the ermA or erm $\mathrm{C}$ genes, may possess the erm $\mathrm{B}$ gene. Due to a possible association of these genes the isolates harboring the erm $\mathrm{A}$ or $\operatorname{erm} \mathrm{C}$ genes may also contain ermB. The presence of the erm $\mathrm{B}$ gene was not researched in our work because it occurs mainly among streptococci and enterococci (Leclercq, 2002). Furthermore, Coutinho et al (2010), reported a low frequency of the ermB gene.

In the present work, it was observed $42.8 \%$ and $70 \%$ of positive isolates for the $h l g$ gene, respectively in the UH and $\mathrm{OH}$, a higher frequency of $98.2 \%$ was found in hospital of India (Aggarwal et al., 2019), the data of UH was similar of Oliveira et al (2014) found $41.86 \%$ of methicillin-resistant CoNS isolates from blood cultures at another University Hospital of the same region and a study in Malaysia reported a percentage of $45 \%$ of methicillin-resistant isolates from patients and students from an university hospital (Lim et al., 2012). The gene $h l g$ codes for the gamma toxin that has pro-inflammatory activity and is capable of lysing erythrocytes and leukocytes, which increases the toxigenic potential of the bacteria and the severity of the infections (Oliveira et al., 2014; Spaan et al., 2014). 
S. aureus and CoNS are able to produce biofilms and this process starts with the adhesion is mediated by the inter cell adhesin $N$-acetyl-glicosamine polimeric (PNAG) which is synthesized by enzymes encoded by genes present in the ica locus (Barbieri et al., 2015; Figueiredo et al., 2017). In our work, there was $25 \%$ and $32.1 \%$ of positive isolates for icaAD, respectively at the $\mathrm{UH}$ and $\mathrm{OH}$. Higher positivity (83.5\%) were detected in Palestinian hospital in isolates of S. aureus (Azmi, Qrei \& Abdeen, 2019), positivity (79\%) was found among inpatients and students in a hospital in Malaysia (Lim et al., 2012). Another study reported $75 \%$ of positive isolates in samples from oncology patients with breast implants (Barbieri et al., 2015).

In this study, there was no statistically significant difference in the presence of the resistance genes (blaZ, mecA, erm $\mathrm{A}$ and $\operatorname{erm} \mathrm{C}$ ) when comparing the two hospitals whilst statistically significant difference was found in the presence of the virulence genes (icaA, icaD and $h l g$ ). This findind suggests that the oncology plays no role on the presence of resistance genes between the groups. On the other hand, the characteristics of the patient groups seems to be associated with the toxigenic and pathogenicity potential of the isolates studied.

The type of the $c c r$ complex was assessed by PCR among the mecA positive isolates from the University Hospital and the $c c r$ type I (ccrA1, 695bp) and type II (ccrA2, $937 \mathrm{bp)}$ were found with higher frequency of $c c r$ type I. Previous studies reported the occurrence of SCCmec types I, II, III, IV and V in Brazilian hospitals (Lima et al., 2014; Oliveira et al., 2015; Andrade-Figueiredo \& Leal-Balbino, 2016). Due to the small mumber of isolates, it was not be possible to make inferences about these findings. It is known that SCCmec types I and II are associated with strains of hospital origin, characterized by multiple antibiotic resistance besides to the betalactams, such as macrolides, aminoglycosides, tetracyclines, quinolones and rifampicin (Andrade-Figueiredo \& Leal-Balbino, 2016).

\section{Conclusion}

The study thus suggests that Staphylococcus strains are drug resistant, virulent, and diverse irrespective of sources and place of isolation. These findings necessitate the continuous surveillance of multidrug-resistant and virulent S. aureus and monitoring of the transmission of infection. The antimicrobial monitoring is essential for the treatment of infections in each hospital.

\section{Acknowledgments}

This work was supported by FACEPE (Fundação de Amparo Ciência do Estado de Pernambuco) grant $\mathrm{n}^{\circ}$ APQ 05792.12/06, PROPESQ (Pró-Reitoria para Assuntos de Pesquisa e Pós-Graduação-UFPE) for the Edital PQ-Multiusuário2010/Propesq n $\mathrm{n}^{\circ}$ 23076.024115/2010-91 and CNPq (protocolo number 474131/2011-4). CAPES for the scholarship provided. The Hospital das Clínicas bacteriology laboratory for providing some samples and CIAC laboratory, Hospital do Câncer de Pernambuco, for providing some samples and information records. Centro de Pesquisas Aggeu Magalhães (CPqAM) for providing space for the molecular techniques realization.

\section{References}

Aggarwal, S., Jena, S., Panda, S., Sharma, S., Dhawan, B., Nath, G. et al. (2019). Antibiotic susceptibility, virulence pattern, and typing of Staphylococcus aureus strains isolated from variety of infections in India. Frontiers in Microbiology, 10:2763. 10.3389/fmicb.2019.02763.

Andrade-Figueiredo, M. \& Leal-Balbino, T.C. (2016). Clonal diversity and epidemiological characteristics of Staphylococcus aureus: high prevalence of oxacillin-susceptible mecA-positive Staphylococcus aureus (OS-MRSA) associated with clinical isolates in Brazil. BMC Microbiology, 16:115. 10.1186/s12866-016-0733-4.

Azmi, K., Qrei, W. \& Abdeen, Z. (2019). Screening of genes encoding adhesion factors and biofilm production in methicillin resistant strains of Staphylococcus aureus isolated from Palestinian patients. BMC Genomics, 20:578. 10.1186/s12864-019-5929-1. 
Barbieri, R., Pesce, M., Franchelli, S., Baldelli, I., De Maria, A., Marchese, A. (2015). Phenotypic and genotypic characterization of Staphylococci causing breast peri-implant infections in oncologic patients. BMC Microbiology, 15 (1), 26. 10.1186/s12866-015-0368-x.

Bezerra Neto, A. M., Rabelo, M. A., Lima, J. L. C., Loibman, S. O., Leal, N. C., Maciel, M. A. V. (2018). Occurrence of the vanA gene in Staphylococcus epidermidis from nasopharyngeal secretion of Health-Care Workers, Recife, Brazil. Revista da Sociedade Brasileira de Medicina Tropical, 51(3), 304-309. $10.1590 / 0037-8682-0159-2017$

Bride, L. L., Pereira, M. F., Barbosa, M. C., Silva, N. C., Klein, N. M., Nascimento, T. C., \& Schuenck, R. P. (2019). Differences in resistance profiles and virulence genes among methicillin-resistant and methicillin-susceptible Staphylococcus aureus of different lineages at a public tertiary hospital. Revista da Sociedade Brasileira de Medicina Tropical, 52, e20190095. 10.1590/0037-8682-0095-2019

Burnham, C. A. D., Weber, C. J. \& Dunne Jr, W. M. (2010). Novel screening agar for detection of vancomycin-nonsusceptible Staphylococcus aureus. Journal of Clinical Microbiology, 48(3), 949-951. 10.1128/JCM.02295-09.

Cagol, A. R., Castro Junior, C. G., Martins, M. C., Machado, A. L., Ribeiro, R. C., Gregianin, L. J., \&Brunetto, A. L. (2209). Oral vs. intravenous empirical antimicrobial therapy in febrile neutropenic patients receiving childhood cancer chemotherapy. Jornal de Pediatria, 85(6), 531-535. 10.2223/JPED.1956.

CLSI (Clinical and Laboratory Standards Institute). (2014). Performance standards for antimicrobial susceptibility testing, twenty-fourth informational supplement, documentM100-S24.Wayne, PA, USA. 2014.

Coutinho, V. L. S, Paiva, R. M., Reiter, K. C., de-Paris, F., Barth, A. L., \& Machado, A. B. (2010). Distribution of erm genes and low prevalence of inducible resistance to clindamycin among staphylococci isolates. The Brazilian Journal of Infectious Diseases, 14(6), 564-568. 10.1016/S1413-8670(10)70113-6

Elboshra, M. M. E., Hamedelnil, Y. F., Moglad, E. H., \& Altayb, H. N. (2020). Prevalence and characterization of virulence genes among methicillin resistant Staphylococcus aureus isolated from Sudanese patients in Khartoum state. New Microbe and New Infect. 38 , 100784. https://doi.org/10.1016/j.nmni.2020.100784.

Figueiredo, A. M. S., Ferreira, F. A., Beltrame, C. O., \& Côrtes, M. F. (2017). The role of biofilms in persistent infections and factors involved in icaindependent biofilm development and gene regulation in Staphylococcus aureus. Critical Reviews in Microbiology, 43(5), 602-620. $10.1080 / 1040841 X .2017 .1282941$.

Fontelles, M. J., Simões, M. G., Farias, S. H., \& Fontelles, R. G. S. (2009). Scientific research methodology: guidelines for elaboration of a research protocol. Revista Paraense de Medicina, 23(3). https://pesquisa.bvsalud.org/portal/resource/pt/lil-588477.

Jenkins, A., Diep, B. A., Mai, T. T., Vo, N. H., Warrener, P., Suzich, J., Stover, C. K., \& Sellman, B. R. (2015). Differential Expression and Roles of Staphylococcus aureus Virulence Determinants during Colonization and Disease. mBio. 6(1), e02272-14. 10.1128/mBio.02272-14

Jiang, A.M., Shi, X., Liu, N., Gao, H., Ren, M. D., Zheng, X. Q. et al. (2020). Nosocomial infections due to multidrugresistant bacteria in cancer patients: a sixyear retrospective study of an oncology Center in Western China. BMC Infectious Diseases. 20, 452. 10.1186/s12879-020-05181-6.

Jones, R. N., Guzman-Blanco, M., Gales, A. C., Gallegos, B., Castro, A. L., Martino, M. D., Vega, S., Zurita, J., Cepparulo, M., \& Castanheira, M. (2013). Susceptibility rates in Latin American nations: report from a regional resistance surveillance program (2011). The Brazilian Journal of Infectious Diseases, 17(6), 672-681. 10.1016/j.bjid.2013.07.002.

Juyal, D., Shamanth, A. S., Pal, S., Sharma, M. K., Prakash, R., \& Sharma, N. (2013). The prevalence of inducible clindamycin resistance among Staphylococci in a tertiary care hospital - A study from the Garhwal Hills of Uttarakhand, India. Journal of Clinical \& Diagnostic Research, 7(1), 61-65. 10.7860/JCDR/2012/4877.2671.

Kang, C. I., Song, J. H., Chung, D. R., Peck, K. R., Yeom, J. S., Son, J. S., \& Wi, Y. M. (2012). Bloodstream infections in adult patients with cancer: clinical features and pathogenic significance of Staphylococcus aureus bacteremia. Supportive Care in Cancer, 20(10), 2371-2378. 10.1007/s00520-011-1353-z.

Kondo, Y., Ito, T., Ma, X. X., Watanabe, S., Kreiswirth, B. N., Etienne, J., \& Hiramatsu, K. (2007). Combination of multiplex PCRs for staphylococcal cassette chromosome mec type assignment: rapid identification system for mec, $c c r$, and major differences in junkyard regions. Antimicrobial Agents and Chemoterapy, 51(1), 264-274. 10.1128/AAC.00165-06.

Kord, M., Ardebili, A., Jamalan, M., Jahanbakhsh, R., Behnampour, N., \& Ghaemi, E. A. (2018). Evaluation of biofilm formation and presence of Ica genes in Staphylococcus epidermidis clinical isolates. Osong Public Health and Research Perspectives, 9(4), 160-166. 10.24171/j.phrp.2018.9.4.04.

Kumar, S., Bandyopadhyay, M., Bhattacharya, K., Bandyopadhyay, M.K., Banerjee, P., Pal, N., Mondal, S., \& Ghosh, T. (2012). Inducible clindamycin resistance in Staphylococcus isolates from a tertiary care hospital in eastern India. Annals of Tropical Medicine and Public Health, 5(5), 468-470. doi:10.4103/1755-6783.105134

Leclercq R. (2002). Mechanisms of resistance to macrolides and lincosamides: nature of the resistance elements and their clinical implications. Clinical Infectious Diseases, 34(4), 482- 492. 10.1086/324626.

Lim, K. T., Hanifah, Y. A., Yusof, M. Y. M., \& Thong, K. L. (2012). Characterisation of the virulence factors and genetic types of methicillin susceptible Staphylococcus aureus from patients and healthy individuals. Indian Journal of Microbiology, 52(4), 593-600. 10.1007/s12088-012-0286-7.

Lima, D. F., Brazão, N. B., Folescu, T. W., Neves, F. P., Ferreira, A. G., Santos, E. A., Marques, E. A., \& Leão, R. S. (2014). Panton-Valentine leukocidin (PVL) gene carriage among Staphylococcus aureus strains with SCCmec types I, III, IV, and V recovered from cystic fibrosis pediatric patients in Brazil. Diagnostic Microbiology and Infectious Disease, 78(1), 59-62. 10.1016/j.diagmicrobio.2013.10.004.

Lina, G., Quaglia, A., Reverdy, M. E., Leclercq, R., Vandenesch, F., \& Etienne, J. (1999a). Distribution of genes encoding resistance to macrolides, lincosamides, and streptogramins among Staphylococci. Antimicrobial Agents and Chemoterapy, 43(5), 1062-1066. 10.1128/aac.43.5.1062. 
Lina, G., Piémont, Y., Godail-Gamot, F., Bes, M., Peter, M. O., Gauduchon, V., Vandenesch, F., \& Etienne, J. (1999b). Involvement of Panton-Valentine Leukocidin- producing Staphylococcus aureus in primary skin infections and pneumonia. Clinical Infectious Diseases. 29(5), $1128-1132.10 .1086 / 313461$.

Milheiriço, C., Portelinha, A., Krippahl, L., de Lencastre, H., \& Oliveira, D. C. (2011). Evidence for a purifying selection acting on the betalactamase lócus in epidemic clones of methicillin-resistant Staphylococcus aureus. BMC Microbiology, 11(1), 76. 10.1186/1471-2180-11-76.

Montassier, E., Batar, E., Gastinne, T., Potel, G., \& de La Cochetière, M. F. (2013). Recent changes in bacteremia in patients with cancer: a systematic review of epidemiology and antibiotic resistance. European Journal of Clinical Microbiology \& Infectious Diseases, 32 (7), 841-50. 10.1007/s10096-013-1819-7.

Muldrew, K. L., Tang, Y. W., Li, H., \& Stratton, C. W. (2008). Clonal Dissemination of Staphylococcus epidermidis in an Oncology Ward. Journal of Clinical Microbiology, 46(10), 3391-3396. 10.1128/JCM.00115-08.

Oliveira, A. A. F., Pinheiro Jr, J. W., Mota, R. A., Cunha, M. L., Lopes, C. A., \& Rocha, N. S. (2011). Phenotype characterization of Staphylococcus species strains isolated from buffalo (Bubalus bubalis) milk. Journal of Veterinary Diagnostic Investigation, 23(6), 1208-1211. 10.1177/1040638711428946.

Oliveira, W. L. M., Ferreira, E. L., Mangueira, E. V. C., Vilela, M. A., Almeida, A. M. P., \& Leal, N. C. (2014). Coagulase-Negative Staphylococci from hospital-associated infections harboring virulence genes. Jacobs Journal of Microbiology and Pathology, $1(2), 013$.

Oliveira, W. L. M., Mangueira, E. V. C., Vilela, M. A., Júnior, S. P., Leal, N. C., \& Almeida, A. M. P. (2015). Diversity of Sccmec types in methicillin resistant Staphylococcus spp. causing hospital-associated infections. Jacobs Journal of Microbiology and Pathology, 2(3), 020.

Panesso, D., Planet, P. J., Diaz, L., Hugonnet, J. E., Tran, T. T., Narechania, A. et al. (2015). Methicillin-Susceptible, Vancomycin-Resistant Staphylococcus aureus, Brazil. Emerging Infectious Diseases, 21(10): 1844-1848. 10.3201/eid2110.141914.

Prabhash, K., Medhekar, A., Ghadyalpatil, N., Noronha, V., Biswas, S., Kurkure, P., Nair, R., \& Kelkar, R. (2010). Blood stream infections in cancer patients: a single center experience of isolates and sensitivity pattern. Indian Journal of Cancer, 47 (2), 184-188. 10.4103/0019-509X.63019.

Quiles, M. G., Menezes, L. C., Bauab, K. C., Gumplv, E. K., Rocchetti, T. T., Palomo, F. S., Carlesse, F., \& Pignatari, A. C. C. (2015). Diagnosis of bacteremia in pediatric oncologic patients by in-house real-time PCR. BMC Infectious Diseases, 15, 283. 10.1186/s12879-015-1033-6.

Rabelo, M. A., Bezerra Neto, A. M., Loibman, S. O., Lima, J. L. C., Ferreira, E. L., Leal, N. C., \& Maciel, M. A. V. (2014). The occurrence and dissemination of methicillin and vancomycin-resistant Staphylococcus in samples from patients and health professionals of a university hospital in Recife, State of Pernambuco, Brazil. Revista da Sociedade Brasileira de Medicina Tropical, 47(4), 437-446. 10.1590/0037-8682-0071-2014

Rabelo, M. A., Bezerra Neto, A. M., Silva, E. C. B. F., Oliveira, W. L. M., Melo, F. L., Lopes, A. C. S., Leal, N. C., \& Maciel, M. A. V. (2013). Phenotypic methods for determination of methicillin resistance in Staphylococcus spp. from health care workers. Jornal Brasileiro de Patologia e Medicina Laboratorial, 49(2), 91-96. 10.1590/S1676-24442013000200003.

Rossi, F., Diaz, L., Wollam, A., Panesso, D., Zhou, Y., Rincon, S. et al. (2014). Transferable Vancomycin Resistance in a Community-Associated MRSA Lineage. The New England Journal of Medicine, 370(16), 1524-1531. 10.1056/NEJMoa1303359.

Saderi, H., Emadi, B. \& Owlia, P. (2011). Phenotypic and genotypic study of macrolide, lincosamide and streptogramin B (MLSB) resistance in clinical isolates of Staphylococcus aureus in Tehran, Iran. Medical Science Monitor, 17 (2), 48-53. 10.12659/MSM.881386.

Sangappa, M. \& Thiagarajan, P. (2012). Methicillin resistant Staphylococcus aureus: resistance genes and their regulation. International Journal of Pharmacy and Pharmaceutical Sciences, 4(1):658-667.

Sedaghat, H., Esfahani, B. N., Mobasherizadeh, S., Jazi, A. S., Halaji, M., Sadeghi, P., Emaneini, M., \& Havaei, A. S. (2017). Phenotypic and genotypic characterization of macrolide resistance among Staphylococcus aureus isolates in Isfahan, Iran. Iranian Journal of Microbiology, 9(5), 264-270.

Silveira, A., Cunha, G. R., Caierão, J., Cordova, C. M., \& d'Azevedo, P. A. (2015). MRSA from Santa Catarina State, Southern Brazil: intriguing epidemiological differences compared to other Brazilian regions. The Brazilian Journal of Infectious Diseases, 19(4), 384-389. 10.1016/j.bjid.2015.04.009

Spaan, A. N., Vrieling, M., Wallet, P., Badiou, C., Reyes-Robles, T., Ohneck, E. A. et al. (2014). The staphylococcal toxins $\gamma$ haemolysin AB and CB differentially target phagocytes by employing specific chemokine receptors. Nature Communications, 5, 5438. 10.1038/ncomms6438.

Vasudevan, P., Nair, M. K. M., Annamalai, T., \& Venkitanarayanan, K. S. (2003). Phenotypic and genotypic characterization of bovine mastitis isolates of Staphylococcus aureus for biofilm formation. Veterinary Microbiology. 92, 179-185. 10.1016/S0378-1135(02)00360-7. 